\title{
21. From fear and turmoil to the possibilities of hope and renewal once again
}

\section{Laisenia Qarase}

The Republic of Fiji Military Forces (RFMF), led by Commodore Frank Bainimarama, plunged Fiji into yet another great crisis when it used force of arms to remove the SDL/Labour multiparty government on 5 December 2006. This act of treason had been building for some time. The Commodore had created fear and anxiety in the minds of the people through a series of threats to stage a coup.

When he finally acted, Commodore Bainimarama brutally knocked Fiji off the course it was then following for a secure and prosperous future, founded on a new political accommodation between the indigenous community and Fiji's ethnic Indian population. He imposed on Fiji a military dictatorship, which unleashed a reign of terror, intimidation and abuse of rights. Three people were killed and countless others subjected to ill-treatment and humiliation. I was threatened with arrest and death. The oppression continues. People are warned of the consequences of speaking out against the regime; some are denied their right of assembly, others have been placed without warning on travel 'black lists'; due process is often ignored; the rule of law is compromised and so is the judiciary. The legally appointed Chief Justice was forced out of office by soldiers, and constitutional processes were not followed in the appointment of an acting Chief Justice. Later, the entire Bench of the Court of Appeal resigned. In February 2008, a newly appointed judge broke the convention of judicial independence when she spoke out forcibly on a highly contentious issue in a public forum. The judge appeared to be siding with one of the regime's supporters. The acting Chief Justice was silent on this unprecedented breach of the rules. The interim Attorney-General tried to excuse it.

A team from the International Bar Association, which had planned a visit to consider the state of the law and the judiciary in Fiji, was refused entry. One member was turned away at Nadi International Airport.

There has been an assault on press freedom, despite an assurance by Commodore Bainimarama that such freedom would be respected. A campaign against the media by the interim government reached a peak when the Australian publisher of a daily newspaper was abducted from his home at night, and flown to Sydney the next morning. He was taken away without money, a change of clothing or even a toothbrush. His abductors cut him off from contact with his family, who 
were left to wonder, in a state of quiet dread, about his fate. In March 2008, a group of journalists from the state broadcasting organisation, were summoned by senior army officers to explain a particular story. The publisher of The Fiji Times was called in by the interim Attorney-General, Mr Aiyaz Sayed-Khaiyum, in what was regarded as another act of intimidation. ${ }^{1}$ There are now calls from a senior minister in the regime, Mr Mahendra Chaudhry, for licensing of the media.

An ill-conceived report on the media industry by an eccentric and inexperienced consultant hired by the Fiji Human Rights Commission - itself seen as a supporter of Commodore Bainimarama - is now under consideration by the government. It contains recommendations which can be interpreted as an attempt to tame media organizations and journalists.

\section{The grip of the military}

In defiance of the international community and the wishes of the people, the military is constantly extending its grip through appointment of senior officers to sensitive and strategic posts in the public service, statutory bodies and state enterprises. When I last checked, about 20 army personnel had been recruited in this militarization of important and vital positions. The current commissioner of police, for instance, was formerly the RFMF's deputy commander. He has distinguished himself by attempting to directly interfere in the judicial process and giving the impression that part of his job is to protect the army. Under his leadership, senior police officers are divided among themselves. It is not surprising that the morale of the force is low and public confidence in the police has slumped. The permanent secretary for Justice is a military man; so is the Director of Immigration, the commissioner of prisons, and the heads of the national post company, the main airport company and the Fiji Independent Commission Against Corruption (FICAC). I am interested to know how FICAC can be independent when it is led by a military officer. This contradiction is typical of the corrupted governance of the interim regime.

The economy, which had been experiencing a prolonged phase of expansion, has been devastated; thousands of our citizens have lost their jobs, poverty has increased dramatically and inflation, at nearly 7.5 per cent, is at its highest level for 10 years.

\section{Incompetence and bad governance}

The interim government, led by Commodore Bainimarama, is establishing new records for incompetence, inefficiency and bad governance, including lack of transparency and accountability, nepotism and cronyism, and failure to follow due process. Opponents of the regime are persecuted, sometimes violently. Stories and suspicions of corrupt, illegal and dubious activities abound. 
Recently, it was revealed by the media that Mr Chaudhry, the leader of the Fiji Labour Party and the interim Minister of Finance, was the senior government figure alleged to have been involved in a well-documented case relating to tax returns. There are also questions about large sums of money held in overseas accounts. Articles about this had been running for many months. Commodore Bainimarama, despite his rhetoric about good governance and openness, stonewalled. He resisted calls for a full public investigation, and for $\mathrm{Mr}$ Chaudhry's resignation to allow this to take place. He seemed to think it was sufficient for the income tax authority to have conducted an internal inquiry! The details of this inquiry have never been made public. Commodore Bainimarama did not appear to understand that the broader issue was about fitness for office, and that an internal inquiry had no credibility. How could the tax department investigate its own minister? It was only when Commodore Bainimarama's own military council - which is probably the final authority in the land - asked for the controversy to be properly dealt with, that the interim Prime Minister finally decided that a three-person committee should conduct investigations. But this fell well short of what was required. The committee was not perceived to be independent, and its terms of reference were inadequate and restrictive. Questions emerged about objectivity and possible conflicts of interest. The committee completed its work secretly, in just a few days, and, by the time the interim Attorney-General made an announcement about it, the two overseas members were preparing to catch a plane out of the country. At no time were details provided about the criteria and procedure for selecting the inquiry members and the drafting of the terms of reference.

It was no surprise at all that the committee found in Mr Chaudhry's favour. This decision, however, was greeted with disbelief by large sections of the public. The local chapter of Transparency International (TI) was a prominent critic of the outcome and called for a new inquiry.

At the time of writing, Mr Chaudhry remained in office.

The interim Attorney-General had the cheek to brag that the inquiry was a study in transparency and accountability. That, again, was an illustration of the regime's bare-faced hypocrisy.

\section{Falsehoods and deception}

Since December 2006, the interim government, established by Commodore Bainimarama, has turned itself inside out to justify its actions. It has become notorious for speaking falsehoods, attempting to deceive, and twisting events and circumstances to suit its own purpose.

The Commodore and Mr Chaudhry have ranted constantly about supposed vote-rigging in the 2006 general election, poor governance by the multiparty government, and a torrent of alleged corruption. Fiji, they said, was descending 
into an abyss. There was no abyss. But there is now, and Fiji has been pushed into it by the coup.

In short, Commodore Bainimarama, Mr Chaudhry and the entire interim regime, invented a chronicle of lies and deceit that they then tried to sell to the people of Fiji, the international community, including the European Union, the Pacific Islands Forum, and even the United Nations.

Unfortunately for both the Commodore and Mr Chaudhry, and their interim cabinet ministers, this wave of falsehoods, unprecedented in the South Pacific, is recognized for what it is - nothing less than self-serving fiction to try to justify the unjustifiable. In the interim regime's realm of propaganda, the truth is violated to become a lie. A lie is paraded as the truth. In particular, comments by Commodore Bainimarama and Mr Chaudhry must always be treated with caution and suspicion. They have a classic credibility problem. The question that must always be asked is: What are the actual facts? How is it possible to verify what is being said?

I have asked myself many times, what has brought Fiji to this dark and desperate time? How could a country, which was progressing well and coming to grips with its challenges, be so broken and so tortured? Why has this been done to us?

\section{A story of violence, hatred and revenge}

Some recent history creates the context for what has happened. It brings out a story of violence, revenge, hatred and thwarted ambition and contempt for the will of the people.

The Soqosoqo Duavata ni Lewenivanua (SDL) party, which I lead, was voted into office for the second time in May 2006. It had joined with the Fiji Labour Party (FLP) in a constitutional power-sharing arrangement that produced a genuinely representative multiracial government. The first attempt to achieve this, following the 2001 poll, did not succeed because of disagreements over what I perceived to be certain conditions set down by the FLP. This led to court action that went against the SDL. My subsequent offer of ministerial portfolios was rejected by the FLP. I do not agree with Mr Chaudhry's perception that the positions I offered were of no consequence.

In 2006, negotiations for a multiparty cabinet, in accordance with the constitution, were ultimately favourable, although there was some hesitation and foot-dragging on Mr Chaudhry's part. He falsely argues that there was no consultation. This took place by letter and telephone discussions between the two of us. The Supreme Court had earlier ruled that consultation did not carry a right of concurrence: I did not have to agree with what Mr Chaudhry specifically demanded. 
Mr Chaudhry finally had to bow to pressure from his own caucus, and the public, who were keen for the FLP to be part of the government.

The end result was a cabinet comprising Fijian and Indian leaders, with clear mandates from their respective electorates. I offered Mr Chaudhry a significant position. He chose not to be a part of this major initiative for multiracial cooperation. I have my suspicions about his motives; they relate to the military coup later in the year, which he was quick to support. He became a key member of Commodore Bainimarama's illegal interim cabinet, strengthening his position to the point that the FLP's policies rule the interim regime.

Despite Mr Chaudhry's refusal to join the 2006 SDL/FLP cabinet and his constant sniping from the sidelines, the ministers generally worked well together, with the possible exception of Mr Lekh Ram Vayeshnoi, a confidant of Mr Chaudhry, and one other FLP minister. It seemed to me that Mr Vayeshnoi was unable to come to terms with the concept of collective responsibility and mutual loyalty amongst ministerial colleagues.

\section{Public support for the multiparty cabinet}

There was continuing support from all sections of the community for this new form of government. Even Commodore Bainimarama joined in the acclamation! This was very strange in view of the plans for a takeover that were already forming in his mind. The multiparty cabinet's policies were based on an amalgam of the SDL and FLP manifestos, and a comprehensive strategic development plan to guide Fiji's progress for a new term of parliament. I felt we had entered an era of hope. The future was indeed one of promise.

I should stress that a statement by Mr Chaudhry that the FLP, as part of the multiparty government, was not consulted on the formulation of the 2007 budget, was a blatant lie. I can think of no polite way of describing this claim. The FLP ministers were represented on all subcommittees of the cabinet, including the budget subcommittee. Extensive budget consultations took place among committee members, and in cabinet. FLP members participated fully and usefully in these deliberations. The intention to increase value added tax (VAT) in 2007 was a revenue measure. As Mr Chaudhry well knows, these are never disclosed to cabinet until the morning of budget day. The reason for this confidentiality should be obvious to anyone.

\section{Recovery from $\mathbf{2 0 0 0}$}

In the SDL's first period of office from 2001, the priority was to repair the massive social and economic damage caused by an insurrection in 2000. George Speight, a businessman, led an armed group into the parliamentary buildings in Suva. Supported by certain elements of the RFMF, Speight and his cohorts took hostage the government formed by Mr Chaudhry when he became prime minister in 
1999. The Speight group was protesting Chaudhry policies that they claimed were anti-Fijian.

For 56 days, Fiji endured near anarchy. Parliament was a prison and a virtual fortress. Law and order collapsed in other parts of the country when Speight loyalists took matters into their own hands. They overran police stations and an entire rural town; Indian farmers and their families were terrorized, their property, belongings and livestock destroyed. Fiji was on the edge of total disaster.

Mr Chaudhry and his colleagues were released following an agreement between Speight and the military. Speight and members of his group were later arrested, tried, and gaoled.

I came to office, at the request of the military, to head a civilian interim administration charged with restoring stability, reviving the economy and getting the country back to parliamentary rule.

Within 15 months from the attempted coup, we went to elections and I led the newly created SDL Party to its first win.

During nearly six years in power, the SDL vigorously promoted reconciliation and social healing, multicultural understanding and national unity. We saw the SDL party as a rallying point for all citizens of Fiji at this critical moment in history. Our message to the nation was that we wanted a unified Fiji, with the rule of law prevailing and the safety and security of citizens and property assured.

We promised to work for the removal of barriers that separated the communities, and to replace animosity and fear with trust and cooperation. There was no racial boundary to our desire to serve Fiji.

This commitment to the welfare of all was embodied in the SDL's symbol of a dove and an olive branch. These represented the Christian ideals that formed our founding values. They spoke of peace, conciliation, rebirth and national renewal.

Our government brought in fresh measures to assist the poor and working people. We were also determined to close the economic gap between the Fijians and the rest of the populace. There was nothing racist about this. The policies we implemented were specifically provided for in the constitution. A guiding principle of the supreme law is that affirmative action and social justice should secure 'effective equality of access to opportunities' for the Fijian people, as well as for other communities, and for all disadvantaged citizens or groups. This constitutional ideal fitted well with our vision of a country where ethnic communities could live in harmony and prosperity. This was about removing inequities and inequalities that posed a threat to social stability. Our party felt 
that failure to address these would put society at peril and deny social justice to a large section of the population.

There has been much distortion and misinformation about these affirmative action policies. They have been wrongly depicted as a deliberate attempt to marginalize non-Fijian communities. We always stressed that there was no intention of depriving others, and that our goal was to create an economy that had space for every citizen, and that generated wealth to be shared fairly. When this was achieved, Fiji would be a happier place and all of its citizens would reap the benefits.

We made it very clear that our government would enact programs of assistance for the poor and needy in every community. And that is exactly what we did. In fact, we were bound to do this by the constitution. Large numbers of the disadvantaged from our Indian and minority communities were recipients of scholarships and student loans, family assistance, support for small business and agriculture, rental subsidies, poverty alleviation and self-help projects. There was a particular focus on getting to grips with the emerging issue of squatter settlements.

Funding for education, health, infrastructure and rural development reached record levels. We conceived and started to put into effect extensive and ambitious schemes for lifting the living standards of rural communities. Combined, these formed a grand plan for remaking the economic and social landscape of the most deprived areas. There was a special focus also on breathing new life into sugar cane farming, which was in decline, mainly because the growers found it difficult to adapt to modern agricultural practices.

As far as I know, these initiatives have been abandoned.

We offered a solution to the sensitive land lease issue following the guiding principle of fairness to landowners and tenants. The proposals we made were a huge improvement over the existing lease terms. They were rejected by the FLP.

\section{Growth in the economy}

Through a consistently applied policy of encouraging private enterprise, we succeeded in creating a very positive business climate leading to a high degree of confidence. Private sector investment began to pick up, approaching 18 per cent of GDP - up from a stagnant 10 per cent when we had come to office. Looked at from another perspective, the combined efforts of government and business generated a 70 per cent increase in investment of private capital.

This had a dramatic effect on expansion of employment, improvements to wages, and economic growth that registered an average of 2.8 per cent of GDP from 2002 to 2006, when it reached 3.6 per cent. The Bureau of Statistics confirmed a rate of 5.6 per cent in 2004 . 
Tourism, Fiji's main industry, enjoyed an unprecedented boom. Its workforce jumped from 43,000 to 50,000. An additional 5,000 jobs were forecast in early 2006. Arrivals were at record highs, with many new projects going forward. The construction industry, a critical indicator of economic performance, also experienced a rapid turnaround. Its workforce grew by several thousand. Shortage of skills became a real problem and plans were put in place to remedy this. Contrast this with the 40 per cent decline in employment in the industry after 2006.

Membership of the Fiji National Provident Fund (FNPF) by wage and salary earners is a good indicator of the numbers of people in permanent paid employment. Total membership of the FNPF at the end of 2005, stood at a record 316,791 . This was a 48 per cent increase over 2001. In 2005 alone, more than 15,000 new members joined the Fund - again showing growth in paid employment.

The number of active employers registered with the FNPF was also a record. It stood at 5,620 at the end of 2005, up 13 per cent from 2002. These employers provide work for the people. In the last three years of our rule, 242 had joined the FNPF annually. Employment growth since the SDL took office was also indicated by the record number of new tax-payers.

Wages and salaries were gradually rising. The effect of this was reflected in the high rate of consumer spending.

Other elements of our economic fundamentals were satisfactory, with foreign reserves at an equivalent of three to four months of imports, and inflation at around three per cent. Government cash flow was sound.

The 2007 budget deficit was expected to be two per cent of GDP. Public debt was 52 per cent of GDP, which was at the higher end of the medium range. The deficit and debt were not about random spending. They were part of a carefully conceived strategy to rejuvenate an economy that had been in crisis-related recession.

Two areas of concern were our balance of payments position and the slow growth of exports. These problems were addressed in the 2007 budget of our multiparty government. They were also dealt with in the government's five-year strategic plan to 2011. An export strategy had been approved for implementation from 2007 to boost overseas earnings.

\section{International endorsement}

The SDL's impressive record of government and economic management can be easily verified. A number of international organizations gave us their stamp of approval. Their independent commentaries and evaluations are an outright 
rebuttal of the wild and dishonest claims about corruption and related issues by the Commodore and Mr Chaudhry.

Endorsements include:

- An Asian Development Bank report described growth under the SDL as solid, and noted the strong performance by the private sector. It listed our external debt outstanding, as the lowest among 12 Pacific Island states.

- The International Monetary Fund also commented favourably on Fiji's economic progress from 2000.

- In October 2005, Transparency International ranked Fiji at 55 in a corruption perceptions index, covering 158 countries. This exposed Mr Chaudhry's untruthful and malicious claim that Fiji was one of the most corrupt countries in the world. This nonsense had to be corrected by the local TI chair. According to the TI findings, Fiji was perceived to have less corruption than nations such as Brazil, Jamaica, Mexico, Poland, China, Sri Lanka, Romania, Argentina, Nepal, Philippines, Venezuela, Pakistan, Thailand, Trinidad and Tobago, India, Iran, Turkey, and Russia. Papua New Guinea, the other Pacific Island country listed, was at 130 on the perceptions list. For our government, Fiji's ranking gave us a benchmark for improvement.

A report by the Commonwealth Business Council classified Fiji as one of the best five performers in 2005 for introducing measures to reduce and eliminate corruption. The assessment was based on a survey of 32 Commonwealth countries. Fiji was ranked 4 for the reliability and effectiveness of its justice system. It was almost level with New Zealand for having balanced and effective business regulation. Fiji also did well in ratings for government - business relations, free media, effective government, efficient administration and future outlook. This survey outcome was not exactly reflective of the doomsday picture painted by Commodore Bainimarama and Mr Chaudhry.

During the SDL's first term, the World Bank ranked Fiji 34 out of 155 countries for ease of doing business. Fiji was well ahead of some nations with developed economies. This World Bank report, highlighting key factors of good governance, again demolishes the argument by the FLP and the military that Fiji was corrupt beyond redemption, and beset by a governance crisis. (It says much that 15 months after the coup, there's not been one conviction of an SDL minister on a corruption charge. I consider charges laid against me by FICAC, in connection with some share transactions from many years ago, to be political persecution. I deny any wrongdoing. At any rate, I dispute the legality of FICAC. It is also not independent because it is led by a senior army officer.)

The positive perception of Fiji was reinforced in an independent assessment by The Australian National University that was published in November 2004. This 
noted there was no sign in Fiji of the widespread corruption that affects some other Pacific Island countries.

Fiji's Public Service Commission had set up a special unit to investigate corruption reports, and make enquiries if there was a suspicion of corrupt activity.

The SDL government enacted a Financial Reporting Transaction Act to counter money-laundering. This resulted in the setting up of a Financial Intelligence Unit to monitor and implement the Act.

A report and review of corruption and bribery laws was tabled in parliament. It was undertaken by the Fiji Law Reform Commission through a committee chaired by Justice Fatiaki, who later became Chief Justice.

Mr Chaudhry is again being less than honest in his reported comments on the issue of anti-corruption legislation. At a cabinet meeting late in 2006, the Attorney-General was instructed to draft an anti-corruption bill to be submitted to parliament the following February. It was to be based on several reports and studies prepared on the instructions of the SDL government.

Despite what Mr Chaudhry alleges, plans for code of conduct and freedom of information legislation were well advanced. Two bills were in the consultative stage in 2006 and were to be tabled in parliament during its sitting in February 2007. Mr Chaudhry would have been well aware of this.

\section{Vote-rigging ploy}

Assertions of vote-rigging are a favourite ploy of Mr Chaudhry, especially when he has lost an election. He began to hammer this theme again after his party failed to get a majority in the 2006 campaign. He did the same in 2001 when the FLP did not get the parliamentary numbers. Commodore Bainimarama was quick to support Mr Chaudhry's predictable rigging refrain in 2006.

The fact is that Fiji does not have a tradition or record of cheating at the polls. No substantive evidence was produced after May 2006. That poll was the most scrutinized in Fiji's political history. A large number of international, regional and local observer groups carefully studied every aspect of it. They all declared that the elections were free and fair, although acknowledging that there was room for improvement in some of the organizational procedures. Of the 71 seats contested, legal action to challenge results was brought in only two constituencies. One was dismissed by the courts, while the other was withdrawn.

\section{Why has Fiji been ravaged?}

In light of the information presented here, and the undoubted progress Fiji was making, I ask again why our country has been ravaged and traumatized by yet another military takeover? The answers lie in the personalities and agendas of Commodore Bainimarama and Mr Chaudhry, and the dynastic ambitions of family 
members of two of our greatest leaders, Ratu Sir Kamisese Mara, and Ratu Sir Penaia Ganilau.

It is not difficult to uncover the root causes of Commodore Bainimarama's action. There is a strong suspicion that it was related to the Commodore's attempts to escape prosecution over the brutal killings of certain soldiers who were part of an attempt to assassinate him in a November 2000 mutiny. The police had complained that their investigations into this affair had been obstructed.

Many people believe the mutiny left deep and enduring scars on the Commander's psyche. This probably helped to propel him along his destructive course. He was also under investigation for other alleged offences, including two intended takeovers of government, and one of sedition. Commodore Bainimarama demanded that the police drop their inquiries into the allegations against him and other senior military officers.

In other words, he was attempting to evade the law. I understand that the police had completed their investigations and the laying of charges was imminent, just before the coup. Commodore Baininmarama had no legal way out of the problems he had created for himself. The only way he could avoid prosecution, was to take illegal action by overthrowing the government.

Another driving force for Commodore Bainimarama is the intense and obsessive dislike he has in his heart for me. I am puzzled by the depth of his feeling. I can only assume that it is linked in some way to the complexities of the situation in 2000 and my subsequent pursuit of a career as an elected leader, with strong voter endorsement. I was no longer an interim, unelected leader. In two elections I received popular backing and naturally followed policies based on the mandates of the electorate.

Commodore Bainimarama was greatly aggrieved when, out of political necessity, I formed a parliamentary coalition in 2001 with a Fijian nationalist group, the Conservative Alliance-Matanitu Vanua (CAMV). It could be that, in Commodore Bainimarama's mind, these MPs somehow became synonymous with those who had tried to kill him in the 2000 mutiny. It is significant that Mr Chaudhry tried to form an alliance with the CAMV. He also needed their numbers to achieve a parliamentary majority. This seems to have escaped Commodore Bainimarama's notice.

The rift between my governments and the military became more clearly defined when there were differences about the possible extension of the Commodore's contract of employment. The Commodore became very abusive in the course of discussions. We eventually agreed, as a gesture of good faith, to extend his term for a further five years. 


\section{The legal position on the military}

On two or three occasions before the military strike of 2006, there were reports of likely attempts by the army to remove the government. A number of senior army officers who spoke out about Commodore Bainimarama's mutinous plans were dismissed. The government was so concerned about what was happening that we asked the President to set up a Commission of Inquiry into the RFMF. The President at first agreed, but later backed away following pressure from the Commodore.

There was a continuing deterioration in our dealings with Commodore Bainimarama despite the government's best endeavours to engage with him in a professional and focused manner.

The relationship between the RFMF and the government should be based on the relevant laws. The constitution - the supreme law - and the Republic of Fiji Military Forces Act provide the statutory framework. Mr Chaudhry, in his criticisms against the SDL, ignores this legal aspect completely. The RFMF Act gives the commander the power to 'hire and fire' military personnel, to exercise discipline and directly control operational matters in the military. $\mathrm{He}$ is accountable to the minister responsible for the RFMF. Section 112 of the constitution provides for the role of the RFMF. This is specific and narrow. Neither the constitution nor the RFMF Act permit the military commander and the military to interfere in the running of government. There is no role for the military in Fiji's politics.

On numerous occasions from 2001 to 2006 the military commander did not respect higher authority, ignored the law and, in fact, became a law unto himself. He has been given wrong legal advice which he relies upon to justify the military's intervention in society. This advice is quite different from the provisions of Section 112 of the constitution. Unless he accepts his proper lawful role as military commander, and as long as he remains in that position, the security risk for the next elected government will be high.

It is a matter of record that disciplinary action had been instituted against Commodore Bainimarama during our time in office. The alleged offences were many and the evidentiary material sound. It was not possible to prosecute, simply because of the power of the gun and the accompanying lack of respect for authority. Dialogue with the Commodore, as suggested by Mr Chaudhry, was not possible because Bainimarama had finally withdrawn from discussions with the government. This is on the public record. Commodore Bainimarama was not removed from the National Security Council (NSC), as erroneously claimed by Mr Chaudhry. The military commander is not a member of the NSC. He attended meetings by invitation and was not invited to some of these because the security briefs from the minister of home affairs were sufficient for the 
government's purpose. And, of course, Commodore Bainimarama himself became the greatest single threat to Fiji's security.

\section{The SDL's 2006 election win}

The SDL's triumph in the 2006 election was a major blow to the Commodore. He had campaigned openly against us - using government resources - in the hope that the electorate would back the FLP or another group, the New Alliance Party. Even when the results were in, he was personally calling certain MPs to persuade them to go with the FLP. He was a man obsessed, but his efforts were to no avail. The statistics show that even his own soldiers supported the SDL. They still do.

I think the SDL's win, with just over 80 per cent of the indigenous vote, was a tipping point for Commodore Bainimarama. It led him towards a psychological point of no return.

What of Mr Chaudhry? What impelled him to be a part of Commodore Bainimarama's desperate plan? In 2000, Mr Chaudhry underwent an excruciating ordeal when he was brutally removed from power, taken hostage and physically assaulted. All right-thinking people sympathize with him. It would perhaps be understandable if he were driven to seek revenge. Knowing him and the dark side of his personality, I believe there is a revenge factor at work here. I think he even harbours a suspicion that the Commodore had a role in his overthrow. That would create an even more complex and negative dynamic within the interim cabinet. Different agendas for different motives - that is the basis for the entire interim government and that is why it is so dysfunctional.

In any event, the Commodore and Mr Chaudhry manage to identify with a common cause against the SDL. The information I received as prime minister confirmed that Mr Chaudhry and Commodore Bainimarama met several times before the coup. One of these meetings was in the FLP office in the parliamentary buildings. I understand Mr Chaudhry took the opportunity to discredit the SDL and made unsubstantiated allegations of corruption and bad governance. These allegations found fertile ground in Commodore Bainimarama's mind.

Another underlying theme is Mr Chaudhry's true feelings about the Fijians. There has been a widespread impression for many years that he has a racist attitude towards them, although he always denies this. Fijian perceptions were reinforced by some of his ill-conceived and insensitive policies when he was prime minister. He continues to be regarded with suspicion by a majority of Fijians. They simply do not trust him.

Since December 2006, the Fijians have been at the receiving end of the regime's so-called 'clean-up' campaign. There is a deep belief that the interim regime's attempts to weaken and devalue Fijian institutions, can be partly laid at $\mathrm{Mr}$ Chaudhry's door. 
I agree with Mr Chaudhry about one thing, and that is that Fiji needs to move away from ethnic polarization and communalism. But this can only be achieved on the basis of trust, respect, and goodwill. These things have to be earned. Mr Chaudhry does not know how to go about this. He has little understanding of the Fijian psyche. These days, if you talk about ethnicity in Fiji, the interim regime says you are racist. I say, it is stupid and delusional in the extreme to pretend that race is not an issue in Fiji. We must deal with the situation as it is, and move on from there. That is what we were doing through our multiparty cabinet, strategic development plan and other initiatives.

\section{Another element in the coup}

Another ingredient in the Bainimarama coup was the political ambitions of the founders of the New Alliance Party of Fiji (NAPF).

The NAPF had been formed by Ratu Epeli Ganilau to contest the 2006 election. Ratu Epeli is the son of one of our great leaders, the late Ratu Sir Penaia Ganilau, who served as deputy prime minister and president. He is married to the eldest daughter of Ratu Sir Kamisese Mara, the pre-eminent figure in Fiji politics for many years, who is viewed as the father of the nation. Ratu Sir Kamisese was the long-serving prime minister and also a former president.

The NAPF and the FLP had created an unofficial alliance for the election campaign. They found a keen partner in Commodore Bainimarama who, by this time, was thoroughly politicizing the RFMF in defiance of the constitution. Regular meetings took place between the Commander and Ratu Epeli Ganilau before and after the 2006 poll. (A few other prominent people, particularly lawyers, were also known to have advised Commodore Bainimarama on a possible takeover of the government.) The NAPF was comprehensively rejected by the electorate. It did not win a single seat. In fact, most of its candidates lost their deposits for failing to secure 10 per cent of the valid votes cast. This failure to win the confidence of the voters did not prevent the NAPF from accepting positions in Commodore Bainimarama's interim regime. The NAPF made it clear that, in its version of democracy, a popular mandate is not necessarily important. It appeared to believe that its candidates were the best and should, therefore, be in government, despite their loss in the elections.

Ratu Epeli Nailatikau, a former Speaker of the House of Representatives, who joined the interim administration as minister for foreign affairs and external trade, is also a son-in-law of Ratu Sir Kamisese Mara. He had been my loyal deputy when I was interim prime minister and he went on to become Speaker. Our government offered him a diplomatic posting when a new Speaker took office.

I sense that there is an expectation by these chiefs that Fiji somehow owes them a living, and that they should be part of any government leadership. That is 
why Ratu Epeli Ganilau and Ratu Epeli Nailatikau came forward so readily to join forces with Commodore Bainimarama. They also had a common link with Commodore Bainimarama as they were both former commanders of the RFMF.

\section{Government at the point of a gun}

In their efforts to pin the fault for Fiji's fate on the SDL, Mr Chaudhry and Commodore Bainimarama grab any opportunity to vilify the SDL and my leadership. We are guilty of countless sins, all within the perspective of their feverish and dishonest claims of 'bad governance'.

They choose to ignore, however, that what they are practising - illegal despotic rule at the point of a gun - is 'bad governance' in its worst form. The only way to get government in Fiji back to legitimacy is through the ballot box. There is no other viable option. Mr Chaudhry used to be a convinced democrat. That has changed. He now believes good governance is a 'necessary pre-requisite' for 'genuine democracy'. This reasoning is warped. Genuine democracy, however that might be defined, is essential for accountability, openness and the checks and balances of government, the rule of law, and an independent judiciary.

\section{Frenzied opposition}

Our opponents worked themselves into a frenzy over three items of legislation. These were the Promotion of Reconciliation, Tolerance and Unity (RTU) Bill; the Indigenous Claims Tribunal; and the Customary Fisheries, or Qoliqoli, legislation. These measures were not 'pushed' through by the SDL, as asserted by $\mathrm{Mr}$ Chaudhry. Since independence in 1970, no other bills were the subject of more democratic consultation and scrutiny than these. The government listened to the public reaction and, as a result, the amnesty provision was to be removed from the RTU Bill.

The Qoliqoli proposal, in particular, was distorted, exaggerated and demonized. The military, the FLP and the NAP then used it as justification for the coup. This issue was not something plucked out of thin air by the SDL. It addressed a grievance the indigenous people had carried since just after the Deed of Cession in 1874. Ownership of Qoliqoli, which for centuries had belonged to the chiefs and people, was transferred to the State. The Fijians raised this on numerous occasions, but nothing was done to correct what they saw as a historical wrong. Previous governments in the independence era had the issue on their agendas. But, for whatever reason, they did not follow through. Perhaps it went into the too hard basket.

In June 1999, however, the legislation found a new champion: Mr Mahendra Chaudhry. When he spoke as prime minister to the Great Council of Chiefs, he pledged that his government would be following up on the 'drafting of legislation to confer ownership rights to all traditional fishing rights owners'. So there it 
is. Mr Chaudhry obviously saw the Qoliqoli project as good governance and social justice. Then he did an unprincipled about-turn for sinister reasons of expediency. When I briefed the military after 2000 on our plans to implement the Qoliqoli legislation and other measures to address Fijian concerns, Commodore Bainimarama and his officers reacted with enthusiasm.

Then collective amnesia set in. Suddenly the Qoliqoli Bill was portrayed by $\mathrm{Mr}$ Chaudhry and Commodore Bainimarama and assorted supporters as legislation heralding the virtual end of the world as we knew it. It would lead to bloodshed, racial division, contravention of rights, and the destruction of investor confidence and tourism.

The wealthy owners of the exclusive Turtle Island Resort in the Yasawa Islands became prime movers against the bill and were in touch with Commodore Bainimarama. They contributed a substantial amount of money to the NAPF led by Ratu Epeli Ganilau, presumably in the hope that when he was elected to parliament he would stop the bill. Unfortunately for the resort's owners, the people did not want Ratu Epeli to represent them.

I did not agree to bipartisan talks on the Promotion of Reconciliation, Tolerance and Unity Bill, the customary fisheries or Qoliqoli legislation, and the indigenous claims tribunal because, as I have said, there were long and extensive democratic consultations on these throughout the country. These consultations were in addition to the detailed scrutiny of these items of legislation by the Parliamentary Sector Committees, in which the FLP was well represented.

The record of previous bipartisan talks on important issues was not impressive. The 2005 Constitution Amendment Bill, the Agricultural Landlord and Tenant Act Amendment Bill, the Native Land Trust Act Amendment Bill were all torpedoed in the House of Representatives by the FLP even though there had been bipartisan agreement on them.

Mr Chaudhry is in fantasy land when he alleges that I did everything possible to split the FLP and undermine its leadership. The truth is that he was having great difficulty coming to terms with the different mode of politics represented by the multiparty cabinet. This was a departure from the confrontational style Mr Chaudhry practises. He simply could not adapt and cope. The FLP at the time was splitting from within, and without any help from me. This was shown on prime time television news for a number of days. It was an exhibition of personal animosities, political gymnastics, intrigue and treachery.

I have provided a reasonably detailed overview of the SDL's track record in bringing Fiji back from near anarchy in 2000, starting the complex business of reconciliation and rejuvenating the economy. The facts discredit Mr Chaudhry's predictable attempts to paint a quite different picture to suit the rationalization that he and Commodore Bainimarama had developed for the coup. 


\section{More misrepresentations}

A number of additional misrepresentations by Mr Chaudhry require comment. In 2006, around 33 per cent of the population were living below the poverty line - and the entire thrust of our policies was designed to address this. There were very good prospects for generally increasing standards of living. $\mathrm{Mr}$ Chaudhry acknowledged the 33 per cent figure when he made his contribution to the budget debate in November 2006. In his 2008 budget address, however, Mr Chaudhry, as interim finance minister, asserted that poverty levels had increased to 50 per cent of the population. This was the equivalent of a confession that poverty had gone up by 17 per cent during the first 12 months of the interim government rule. Even Mr Chaudhry would have difficulty attributing this to the SDL! It was the coup that pushed more people into poverty - the coup combined with Mr Chaudhry's mismanagement of the economy. The job is simply beyond him.

Mr Chaudhry criticizes the agreement signed in 2006 between the Public Sector Unions (PSU) and the government. This was no different from the industrial relations framework signed in 2000 between the PSU and Mr Chaudhry's government. It covered the three years 2000-2003 and contained provisions for merit and cost of living allowance (COLA) increases. The 2006 agreement, which he condemns, was for the period 2003 to 2008. It also included merit and COLA increases. If the 2006 agreement was unethical, then, by Mr Chaudhry's logic, the same would apply to the 2000 agreement. However, there was nothing unethical about what we negotiated in 2006, it was designed to create long-term stability and efficiency in the public service. I question the $\$ 200$ million cost estimate put forward by Mr Chaudhry. The correct figure should be lower than this. In any case, under the SDL leadership, the government had the capacity to meet the additional cost - hence the agreement with the PSU.

Mr Chaudhry must accept a very large part of the responsibility for unsustainable public service wage and salary costs. In the 1970s, when he was general secretary of the Fiji Public Service Association, he was the initiator of two-tier salary/wage increases with a merit pay and COLA component. Through his bullying tactics against the Alliance government of Ratu Sir Kamisese Mara and then the SVT government of Mr Sitiveni Rabuka, he got away with huge increases. He was warned that government could not afford these, but he did not listen. As the consequence of this, the national operating budget has been squeezing out the capital budget.

When the SDL government decided to stop COLA payment in 2005, the issue was referred to arbitration. The arbitrator ruled in favour of the PSU. COLA continued. The SDL government believes that, as long as the current two-tier salary/wage increase system is in place, the allocation of adequate funds for 
capital expenditure will not be possible, unless there is continuing economic expansion.

\section{Coup convicts}

Mr Chaudhry makes an accusation that I released 'coup convicts from prison and continued to pay a number of their salaries while they were in prison'. This is another lie. I did not release any coup convicts. I had no power to do this. Such releases were legally done by the appropriate authorities, following proper and lawful procedures. Payment of salaries, while in prison (if this happened) was a matter between a convicted person and his employer. Mr Chaudhry is vulnerable when he talks about this issue of early release. He was sent to prison for a traffic offence which resulted in the death of a woman in Suva. He was to serve a nine months sentence but was released from prison after only two weeks, to serve his sentence extramurally. What is the difference between the way $\mathrm{Mr}$ Chaudhry's sentence was administered and the administration of the sentences of the coup convicts he mentions?

Mr Chaudhry is telling lies again when he accuses the Qarase government of interfering with the judicial processes involving those charged with treason and other criminal activities associated with the May 2000 coup and the military mutiny later that year.

The SDL government never interfered with the processes of the judiciary and the law. Neither did it interfere with police investigations into the events of 2000. We knew it was important that justice should be done for the sake of the country and its people.

During six years of our rule, about 3,000 police investigations into the 2,000 insurrection and related matters were completed. Some 800 offenders were convicted. As for Peter Ridgway, the Deputy Director of Public Prosecutions, his contract expired and he did not want it extended. It is instructive to compare the legal record over what happened in 2000 with the omissions and failures of the interim government in relation to the 2006 coup d'état. The leading perpetrators of the 2000 insurrection were held accountable for their actions before the law. The same cannot be said for those who conducted the 2006 takeover. They have tried to gain immunity through a promulgation by the President of questionable legality.

At least three deaths of people in military/police custody remain unresolved. The police give no sign of being interested in investigating numerous cases of physical abuse by military personnel. Complaints about the illegal and indeed brutal behaviour of the interim government have been brushed aside. $\mathrm{Mr}$ Chaudhry's silence, and that of Commodore Bainimarama, in relation to all the intimidation, threats and ill-treatment is deafening. 


\section{The Duavata Initiative and FLP secrecy}

The purpose of the Duavata Initiative Limited (DIL) has been twisted by $\mathrm{Mr}$ Chaudhry on many occasions. The establishment of the DIL to raise funds for the SDL, and for other purposes, was based on similar initiatives in Australia. It was done in a transparent manner and widely publicized. The annual returns of the DIL are filed with the Registrar of Companies.

Compare the accountability and openness surrounding the DIL, with the secrecy which envelops FLP finances. Large amounts of money have been raised by $\mathrm{Mr}$ Chaudhry overseas. But the details of these are hidden and there is much confusion about what these funds are for. There is public concern about this.

Mr Chaudhry's claims that checks and balances for good governance were being constantly undermined by the SDL, does not stand up to scrutiny. His allegations that parliamentary procedures and standing orders were often suspended to stifle debate and to ensure the easy passage of SDL legislation are untrue. $\mathrm{Mr}$ Chaudhry's performance in terms of following parliamentary procedures was appalling. During the 12 months he was in office, as prime minister, about 40 to 50 bills were passed. Most of these had less than one day with Sector Committees. A good example was the bill for government to take over \$27 million in loans owed by cane farmers to the Fiji Sugar Cane Growers Fund Authority. The cane farmers form a vote bank for Mr Chaudhry. This legislation, involving a large commitment of public funds, was one of those items that was dealt with in the relevant Sector Committee in just a few hours.

\section{A faltering charter}

The interim government is pouring funds and resources into the drafting of a 'People's Charter', which, it says, will provide a new, binding blueprint for Fiji. The charter is to be a panacea for every national ill, real and imagined.

However, large sections of the population and many community groups, are not supportive of this initiative. They believe it is a device by the interim regime to gain some form of legitimacy and vindication for the spurious case it has created for the removal of the multiparty government.

Commodore Bainimarama has expressed anger at the opposition to the charter plan. He has said many times that, if the population will not support it, then Fiji will not go to the polls in the first quarter of 2009. This timetable follows a commitment he gave to the people of Fiji and the international community in October 2007. But ever since then he has been equivocating. Now he is consistently linking the election to the charter.

The SDL bases its opposition on the following:

- There is doubtful legal authority for the proposed charter. 
- The charter process lacks independence and autonomy - it is driven by the interim government and the military.

- Commodore Bainimarama has no popular mandate for the preparation and implementation of such a major initiative.

- The stated intention for the charter - to bind future elected governments for the next 15-20 years - is unacceptable; this is authoritarian and undemocratic.

- Suggestions that the provisions of the charter might be used to bring about constitutional and electoral change again raise fundamental issues. It is not the place of an interim government, backed by guns, to take such actions.

Many people believe that Mr Chaudhry is the initiator of the charter and that it will become a virtual manifesto for the FLP.

Commodore Bainimarama has said that the charter will provide him with an 'exit strategy'. The SDL submits that a viable exit for Commodore Bainimarama and the interim cabinet is through a political solution to our national crisis. The People's Charter cannot provide this solution. In fact, it has become divisive and created further divisions in the community.

\section{A new road to elections}

A first step towards legitimacy is for a political forum to be established of the parties represented in the 2006 election and other key stakeholders. The task of this forum would be to discuss and negotiate on the issues that must be resolved, including the complex matter of amnesty. Preparations for a general election by March 2009 should proceed without delay. We have proposed to Commodore Bainimarama a pathway towards a poll. The main points are:

- $\quad$ Recall the 2006 parliament by late 2008.

- The interim government to resign just prior to the recall of parliament.

- The parliament will meet for one or two weeks to address crucial legislative and other matters.

- A small cabinet, consisting of parliamentarians, to be responsible for the affairs of government while the parliament is in session.

- I will tender my resignation as prime minister, and advise the President to dissolve parliament.

- A caretaker cabinet will take the country to a general election by March 2009.

This proposal is based on the provisions of our constitution and other laws. It is designed to ensure that the relevant legislation is followed as far as is practicable.

Fiji is going through a national nightmare. But if there is a willingness to act in the national interest and put hatred and anger to one side, then our country can 
rise again. This will not be easy but we must never abandon hope and we must never stop believing in what is possible.

God bless Fiji.

\section{ENDNOTES}

${ }^{1}$ In May of 2008, he too was expelled from Fiji. 